\title{
On incorrupt government connotation of pre-Qin Confucianism's idea of moral and profit
}

\author{
Shaohua Yan \\ School of Marxism Studies, China Three Gorges University, \\ Yichang, 443002, China
}

Keywords: Incorrupt; Pre-Qin Confucianism; Idea of moral and profit

\begin{abstract}
Pre-Qin Confucianism's idea of moral and profit is featured by several perspective and profound connotation. Pre-Qin Confucianism's idea of moral and profit represented by Confucius, Menci and Xuncuis contains abundant content, such as 'taking profits under the premise that righteousness is respected', 'righteousness first and profits later' and 'following righteousness is honorable and taking profits humiliating'. Pre-Qin Confucianism's idea of moral and profit is important theoretical resources for construction of incorrupt government culture in China and has enlightenment and significance for value selection of modern politicians, selection between righteousness and profits in conflicts and cultivation about morality about 'following righteousness is glorious and taking profits humiliating'.
\end{abstract}

\section{Introduction}

By virtue of its multi-dimensional perspectives and profound connotation, idea of moral and profit enriches traditional thought of clean government in China. Pre-Qin Confucianism treats maintenance of stale social order as a value mission and tries to standardize politicians' moral behaviors from the perspective of righteousness and profits in order to ensure their political effectiveness. Neither incorrupt moral self-discipline nor heteronomy can be neglected. 'However, if external heteronomy cannot be approved by individuals, it will exist in name only and fail to change passive compliance into active observation or covert external requirements into internal criterion, which is useless for social governance. ${ }^{[1]}$ It is obvious that idea of moral and profit is indispensable for administers and politicians. Therefore, it should be helpful to master politicians' acceptance or rejection about righteousness and profits and explore their value orientation from the perspective of incorrupt government.

\section{Connotation of 'righteousness' and 'profit'}

As an important component of Chinese incorrupt government culture, idea of moral and profit is both a basis on which politicians take profits and a moral requirement for politicians, which has rich connotation logically. Connotation of 'righteousness' and 'profit' is not completely the same among different groups. Clear theoretical foundation may be provided for analysis about pre-Qin Confucianism's idea of moral and profit with incorrupt government standpoints if we discuss requirements for politicians.

Righteousness refers to sacred ethical principles established by subjects in the process of practice, treats beauty and virtue as the highest moral value it pursues and is a lofty realm that people hopes to reach [2]. Profit stands for the interest or utility that subjects pursue in the process of practice and is material pursuit realized by people via hard work in reality.

In traditional clean government culture of China, righteousness and profit have countless relations with economic field [3]. Just as Marx said, 'Everything that people strive for by hard work is related to their interests' [4]. We may explain this from the perspective of incorrupt government, i.e., public benefits equal 'righteousness', while individual profits equal 'profit'. Righteousness and profit are reflection of traditional clean government culture of China in economic field. On the other hand, there are impacts of other factors in the process of economic activities in addition to 
economic interests, such as political purpose and value orientation etc. Politicians should be incorrupt, diligent and expert in political affairs since politicians who master public power to distribute social resources face with various conflicts of interest and interest selection and their behavioral selection must be carried out under some value orientations.

From an ethic perspective, righteousness and profit are two value orientations with different connotation, which politicians pursue from their own perspective. Since politicians master public power, they may pursue and desire for profits when they are tempted by internal desire and external environment. 'Righteousness' refers the moral obligation that politicians should undertake in the process in which they are political officials according to their social roles. 'As a value orientation, it just directs at changing people's behaviors and relations from 'existing ones' to 'proper ones' [5]'. Profit is an expected purpose and actual result of material value that politicians try to realize when they are political officials.

From the perceptive of values, righteousness and profit is a special subject-object relationship. In other words, politicians' behavioral activities and results are treated as objects to evaluate its relationship with politicians. Righteousness can satisfy politicians' moral needs and acts as spiritual value that politicians pursue inside and their life intentions and political ideals, while profit refers to external material value needed by politicians and value judgment made by politicians on profit and loss of their own behaviors and political performance when they are political officials.

\section{Content of pre-Qin Confucianism's idea of moral and profit with incorrupt government standpoints}

Pre-Qin Confucianism deems that righteousness and profit can not only adjust people's daily life but also have methodology and guidance value on politicians to administer a country and govern political affairs. Pre-Qin Confucianism advocates Pre-Qin Confucianism between 'righteousness' and 'profit' and thinks that politicians are good ones as long as they place righteousness and profit at a correct position and have a good idea of moral and profit.

(I) Confucius' idea of moral and profit. First of all, Confucius thinks that the behavior that politicians follow righteousness to take profits does not damage their incorrupt righteousness. In Confucius' opinions, righteousness and profit are not two separated extremes and 'righteousness first and profit second' does not mean we only need 'righteousness' and abandon 'profit'; on the contrary, 'profit' derives from 'righteousness' and 'profit' will benefit people. Confucius deems that pursuit of profit is human nature. However, if they pursue profits excessively, difficulty in people's livelihood will be caused and social order will be out of control; in case pursuit of profits is indulged, official righteousness will shrink and support of people will even be lost and huge social ills will be resulted in finally.

Secondly, Confucius thinks that politicians should pay attention to pursuit of public benefits. Confucius' idea of moral and profit aims at pursuing unity of two public interests, including pursuit of people's public interests and maintenance about profits of ruling class. On the one hand, Confucius advocates it is necessary to satisfy people's legitimate interests. On the other hand, governance and profits of the ruling class should be maintained by ensuring people's interests. Interests in the two aspects supplement each other and interlace with one another to form uniform public interests.

Thirdly, Confucius thinks that politicians should have long-term and overall insight. Politicians' selection about righteousness and profits is related to destiny of a nation, the society and people. Confucius warn politicians that they should not pay much attention to speed of political performance but perform real deeds by carrying out policies, such as 'giving in charity widely to help people', 'educating' and 'enriching'. On the other hand, Confucius deems that politicians mastering public power should treat the relationship between righteousness and profit correctly and not covet private interests but regard pursuit of public interests as a political responsibility that they should undertake and pay attention to important affairs. Only in doing so can covet be realized.

(II) Menci's idea of moral and profit. Menci inherits and develops Confucius's idea of moral and profit. On the one hand, he emphasizes value connotation of 'righteousness' and will not refuse 
under any circumstances even 'his like has to be laid down for a just cause'. On the other hand, he actively dispels value and significance of 'profit' and advises monarchs not to 'say profit' to form the value that righteousness is expensive and profit is cheap.

Firstly, Menci thinks that 'righteousness' is conscientious improvement in people's kind extreme. Menci treats 'righteousness' as nature from people's sense of shame instead of a compulsive requirement that externally added to people. People's self-worth and social value can be realized only when they follow this standard consciously. In Menci's opinions, 'profit' is limited and must exist transcendentally. More instinctive values exist beyond 'profit', i.e., 'righteousness'. Politicians use 'righteousness' as a standard when they accept or reject profit'. Because people have ideas, such as guilty, like and dislike, they will avoid disobeying moral rules and can externalize the sense of shame from the heart into 'righteousness'.

Secondly, Menci deems that 'righteousness' holds a high position in value system, holding that the standard used to judge whether a person's self-value can be realized or not is not high official positions and riches but 'righteousness'. In his opinion, profit is an instinctive and lower-grade desire, while kindheartedness and justice are a fundamental and higher-grade pursuit. Politicians cannot abandon virtue and righteousness for high official positions and riches. Real maximum profit can be brought to a country only when virtue and righteousness are carried out. Under contrast of maximum profit, other material interests can only be considered to be petty profits.

Thirdly, Menci deems that 'righteousness' is a standard judging whether self-value is realized or not. In his opinion, although people pursue official rank by fair means or foul can realize their purpose temporarily, they cannot reflect their own value really and cannot be considered to be 'real men' with indomitable spirit since they lack pursuit of 'righteousness'. Menci thinks that three conditions are needed for a person to establish correct values, i.e., occupying benevolence, taking behaviors established by rule of propriety and carrying out righteousness. In Menci's opinion, the spiritual core of 'benevolence' and code of conduct of 'propriety' advocated by Confucianism must be realized by 'righteousness'.

(III) Xuncius' idea of moral and profit. Presupposing evil of human nature, Xuncius pays much attention to system construction and politicians' righteousness. He thinks that politicians are incorrupt as long as hey place righteousness and profit at a correct position and have a good idea of moral and profit.

First of all, Xuncius deems that 'righteousness' can adjust conflicts between people's material demands and resource supply. He advocates that it is essential to use righteousness to be a guidance principle to adjust conflicts between demands and supply. Xuncius advocates people's reasonable material requirements should be satisfied to continue human beings and material wealth. The reasonable material interest mentioned by him means corresponding treatment specifications are offered to people in different social classes by provisions about propriety and corresponding interest distribution is carried out according to the treat specification. The distribution principle is 'righteousness'. Xuncius thinks that the ruling class plays a critical role in comparison between 'righteousness' and 'profit' and their selection about 'righteousness' and 'profit' has significant influence on general mood of society. Therefore, general mood of society hopes politicians can learn from general mood of society to use 'pursuit of righteousness' to overcome 'desire for profits' and govern a country by using righteousness to restrain profit.

Secondly, Xuncius thinks that persistence about 'righteousness' relates to formation of the social atmosphere that incorruption is honorable and corruption is discreditable. Xuncius elaborates his idea of moral and profit from the perspective of honor and disgrace. Xuncius specially emphasizes that should use 'righteousness' to govern a country and affect general mood of society. Politicians who take righteousness first and profits second can guide and help social members to form correct outlook for honor and dishonor and the ones who takes profits first and righteousness secondly are negative examples and show a reverse outlook for honor and dishonor to social members. If politicians use 'righteousness' as a standard of behavior, people will follow examples; in case politicians pursue profits excessively, the public will also behave in this way. This is also a boundary separating social incorruption and corruption. It can be concluded that the thought of 
clean government contained by Xuncius' idea of moral and profit advocates the social atmosphere that incorruption is honorable and corruption is discreditable should be formed in the whole society on the premise that 'righteousness is used to restrain profits'.

\section{Enlightenment of pre-Qin Confucianism's idea of moral and profit on contemporary politicians' selection about righteousness and profit}

Pre-Qin Confucianism's idea of moral and profit and its profound connotation and unique perspective are important theoretical resources for construction of incorrupt government culture in China. In the process in which pre-Qin Confucianism's idea of moral and profit is constructed, the whole ideological system including the moral-profit relationship that righteousness should be obeyed to take profits, the internal thinking that humanity is kind as well as the moral feeling that 'following righteousness is honorable and taking profits humiliating' provides enlightenment that can be used for reference by contemporary politicians when they choose righteousness and profit.

Firstly, politicians should treat 'righteousness' as an important value form of value system. Pre-Qin Confucianism specifies people's righteousness from the perspective of humanity and uses 'righteousness' to rule that politicians should become moral people and have the ability to 'internalize 'righteousness' in heart and externalize it in political affairs, promote righteousness of the whole society and create public interests'. For politicians, selection on moral value is their primary motivation in both mentality and behavior. Practice of moral values is the first mode of their political behaviors. Politicians should be based on 'righteousness' at the level of values, consider 'righteousness' is higher and more important in property of values and deem that 'righteousness' is the highest good, most valuable and worthy of pursuing.

In fact, 'righteousness' contains 'profit' and points at common interests of a larger interest group. Pre-Qin Confucianism thinks that 'emperors and all officials should set up a standpoint of deontology and do deems about 'interests of people' first when they deal with political affairs' [6]. The thought that treats righteousness as profits neither means the final purpose of pursuit of righteousness is to obtain profits nor seeks profits in the name of righteousness but sincerely believes in righteousness, pursues righteousness and defends righteousness firmly and then contains profits.

Secondly, politicians should treat righteousness first and profits second in conflicts between righteousness and profit. Pre-Qin Confucianism regards advocating 'righteousness' as the process in which morality and ideal personality a person should have are cultivated and correct choice at a critical moment sufficiently reflects situations about cultivation of morality and ideal personality at ordinary times. Menci used to take 'life' and 'righteousness' as an example, showing that his value choice that 'he laid down his life for a just cause' in conflicts between righteousness and profit. 'Righteousness first' is the highest realm of the spirit that morality comes first in pre-Qin Confucianism's values, which encourages numerous politicians to devote themselves to interests of a country and a nation bravely. This part of content is also a splendid part in Confucianism's thought of clean government.

Thirdly, politicians should have the morality that 'following righteousness is honorable and taking profits humiliating' [7]. Pre-Qin Confucianism deems that politicians can be accepted by the public really, affect the public by morality education and make their good morality be widely accepted in the society and form an atmosphere of clean government only when they have the morality that 'following righteousness is honorable and taking profits humiliating. Since an incorrupt politician should be a person with morality, he may apply spiritual strength to bring wealth to the society and then utilize wealth to perfect and develop the public's morality, which is also the spiritual effect of politicians' morality. A person's morality decides his attitude towards wealth. If he treats morality comes first, the will not pursue power and influence deliberately. If politicians consider 'righteousness' comes first, a good social atmosphere, where righteousness is emphasized, will be formed in the whole society. If politicians consider 'profit' comes first, a bad social atmosphere, where people pay excessive attention to profits, will be formed. If politicians are 
honest and upright, the social atmosphere that incorruption is honorable and corruption is discreditable will be formed in the whole society.

\section{Conclusion}

Although pre-Qin Confucianism's idea of moral and profit weakens effect of other social codes like laws and rules, a number of theoretical opinions are worth inheriting and promoting. Research on pre-Qin Confucianism's idea of moral and profit in the new historical period can make excellent thinking resources show their unique elegant demeanor under the new situation and is of important significance for comprehensive cognition and comprehension about the traditional virtue of incorrupt government, excavation and utilization of traditional clean government culture achievements and construction of clean government culture with Chinese socialism

\section{Acknowledgments}

This thesis is 1) a humanistic and social science research project of Hubei Provincial Department of Education, task name is Pre-Qin Confucianism's Thought of Clean Government and Its Contemporary Enlightenment and project No. is 2012Q028 and 2) a project funded by social scientific fund of China Three Gorges University, task name is Research on Pre-Qin Confucianism's Thought of Clean Government and Its Contemporary Value and project No. is KJ2011B063.

\section{References}

[1] Li Zhiqiang. Journal of Hunan University of Science Technology(Social Science Edition) [J], 2011(05).

[2] Wang Zeying. Idea of Moral and Profit and Economic Ethics [M]. Hunan People's Publishing House, 2005, pp. 11.

[3] Yang Qingrong. Confucian political ethics under economic globalization [M]. China Social Sciences Publishing House, 2006, pp. 199.

[4] Marx and Engels Anthology [M]. People's Publishing House, vol. 1, 1995, pp. 82.

[5] Zhu Hailin, Shi Pingting. Journal of Hunan University of Science Technology(Social Science Edition) [J], 2008(2).

[6] Yang Jianxiiang. Confucianism official morality [M]. Jiangxi People's Publishing House, 2007, pp. 281.

[7] Zhou ZIqiang. Historical experience in pre-Qin construction of a clean government and anti-corruption [M]. Anhui Education Publishing Press, 2012, pp. 319. 